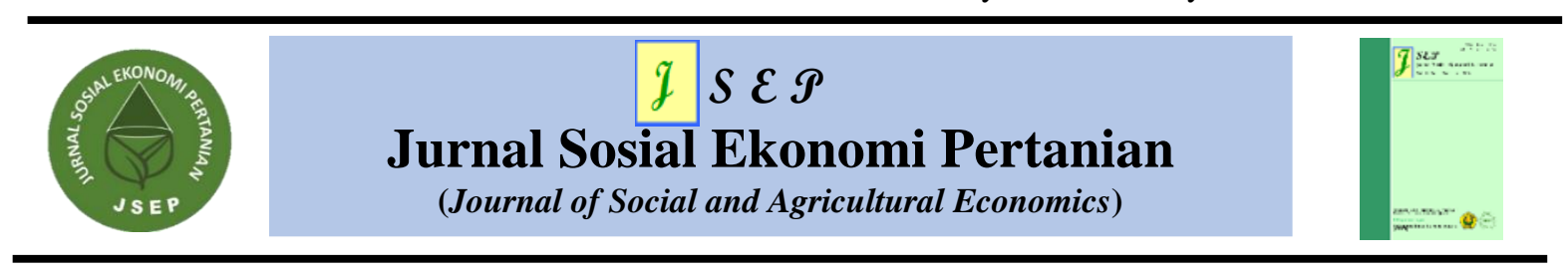

\title{
CORPORATE SOCIAL RESPONSIBILITY (CSR) PT. FINNANTARA INTIGA MELALUI PROGRAM DESA MAKMUR PEDULI API (DMPA) BIDANG PERTANIAN PANGAN
}

\section{CORPORATE SOCIAL RESPONSIBILITY PT. FINNANTARA INTIGA TROUGH DESA MAKMUR PEDULI API (DMPA) BASE ON FOOD AGRICULTURE}

\author{
Ricca Gideon ${ }^{1}$, Eva Dolorosa ${ }^{1 *}$ dan Josua Parulian Hutajulu ${ }^{1}$ \\ ${ }^{1}$ Prodi Agribisnis, Fakultas Pertanian Universitas Tanjungpura \\ *Corresponding author's email: eva.dolorosa@faperta.untan.ac.id
}

Submitted: 30/04/2021 Revised: 14/07/2021 Accepted: 31/07/2021

\begin{abstract}
The Desa Makmur Peduli Api (DMPA) Program is a form of Corporate Social Responsibility (CSR) from $P T$. Finnantara Intiga. This program aims to empower the local community in a productive economic sector which focuses on increasing the local people's income. The various DMPA programs that have been prepared are fish farming, cattle farming, rice, and corn farming. Based on the results of the study and agreement with the local community, the DMPA program focuses on corn farming. The purpose of this study was to determine a strategy to improve the performance of corn farming. The research method uses descriptive methods with SWOT analysis tools to determine strategic alternatives and QSPM analysis to select strategic priorities. The respondents consisted of 4 key informants and 18 regular informants for SWOT analysis and 4 experts for QSPM analysis. The result of the SWOT analysis is WO (Weakness Opportunity) strategy with 4 alternative strategies. Based on the results of the QSPM analysis, the priority strategy is for the company have to collaborate with the government to train farmers routinely.
\end{abstract}

Keywords: CSR, corn farming, QSPM, SWOT

\begin{abstract}
ABSTRAK
Program Desa Makmur Peduli Api (DMPA) merupakan bentuk tanggung jawab sosial perusahaan dari PT. Finnantara Intiga berupa program pemberdayaan masyarakat dalam sektor ekonomi produktif yang menitikberatkan pada peningkatan pendapatan masyarakat lokal. Berbagai program DMPA yang disusun adalah budidaya ikan, ternak sapi, usahatani padi dan jagung. Berdasarkan hasil kajian dan kesepakatan dengan masyarakat, program DMPA focus pada usahatani jagung. Tujuan penelitian ini adalah menyusun strategi untuk meningkatkan kinerja usahatani jagung. Metode penelitian menggunakan metode deskriptif dengan alat analisis SWOT guna menentukan alternatif strategi dan analisis QSPM untuk memilih prioritas strategi. Responden berjumlah 22 orang, terdiri dari 4 informan kunci dan 18 orang informan biasa untuk analisis SWOT dan 4 orang pakar untuk analisis QSPM. Hasil analisis SWOT mengarah ke strategi WO (Weakness - Opportunity) dengan 4 alternatif strategi. Berdasarkan hasil QSPM, strategi prioritas adalah perusahaan bekerja sama dengan pemerintah untuk melakukan pembinaan rutin kepada petani.
\end{abstract}

Kata Kunci: QSPM, SWOT, tanggung jawab social, usahatani jagung

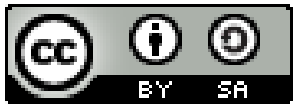

Copyright $@ 2021$ by Author(s)

This work is licensed under a Creative Commons Attribution-ShareAlike 4.0 International

License. All writings published in this journal are personal views of the authors and do not represent the views of this journal and the author's affiliated institutions.

How to Cite: Gideon, R., Dolorosa, E., dan Hutajulu, J.P. (2021). Corporate Social Responsibility (CSR) PT. Finnantara Intiga Melalui Program Desa Makmur Peduli Api (DMPA) Bidang Pertanian Pangan. JSEP: Jurnal Sosial Ekonomi Pertanian, 14(2): 125-139. 


\section{PENDAHULUAN}

Tanggung jawab sosial perusahaan atau Corporate Social Responsibility (CSR) merupakan komitmen perusahaan untuk berperilaku etis secara berkelanjutan, beroperasi secara legal, berkontribusi dalam pengembangan perekonomian masyarakat yang tinggal di sekitar perusahaan (Santoso, 2016). Peraturan tentang CSR di Indonesia telah diatur pada pasal 74 UU No. 40 Tahun 2007 tentang perseroan terbatas guna mewujudkan pembangunan ekonomi berkelanjutan untuk meningkatkan ekonomi bersamaan dengan peningkatan kualitas lingkungan hidup masyarakat yang tentunya akan bermanfaat bagi perseroan itu sendiri. PT. Finnantara Intiga bergerak di bidang industri pengelolaan hutan tanaman industri (HTI), memiliki kawasan luas dan berdekatan dengan lokasi pemukiman masyarakat sehingga secara langsung maupun tidak langsung akan bersentuhan dengan lingkungan sekitar.

Program CSR yang dilakukan PT. Finnantara Intiga selalu mengutamakan permasalahan vital yang dihadapi masyarakat dalam peningkatan kesejahteraannya. Salah satu persoalan yang dihadapi adalah tingkat ekonomi yang rendah dari masyarakat sekitar kawasan hutan. Hal ini disebabkan mayoritas masyarakat masih menjalankan pola pertanian ladang berpindah yang membuka lahan baru dengan cara membakar lahan. Hal ini dapat menyebabkan hasil usahatani menjadi kurang maksimal dan dapat merusak lingkungan terutama lingkungan biotik pada tanah. Program CSR PT. Finnantara Intiga bertujuan untuk meningkatkan kesejahteraan masyarakat di area konsesi, dengan melaksanakan program Desa Makmur Peduli Api (DMPA), yaitu berupa pemberdayaan masyarakat dalam sektor ekonomi produktif yang menitikberatkan pada peningkatan pendapatan masyarakat lokal, dan mampu berdaya saing sehingga tercipta 1 (satu) unit usaha dalam Desa, serta menjadi bagian dari salah satu alternatif solusi upaya pencegahan kebakaran hutan dan lahan. Program ini juga sejalan dengan upaya pemerintah, mengembangkan berbagai inovasi sebagai perwujudan komitmen terhadap tercapainya Sustainable Development Goal's (SDG). Penelitian Nikoyan et al. (2019) menyatakan implementasi CSR lebih bersifat pada upaya memenuhi kebutuhan masyarakat dan kepentingan berbagai pihak, yang direalisasikan dalam bentuk pemenuhan kebutuhan dasar masyarakat sekitar dalam hal membuka lapangan kerja dan menyediakan sarana prasarana. Penyusunan program DMPA oleh PT. Finantara Intiga di bidang pertanian pangan adalah budidaya padi dan jagung, peternakan sapi, perikanan nila \& lele. Berdasarkan hasil kajian dan diskusi antara PT Finnantara Intiga dan masyarakat local, telah menyepakati bahwa komoditas tanaman yang berpotensi untuk dikembangkan dan sesuai dengan kondisi lingkungan desa Mengkiang adalah komoditas jagung. Jagung ditanam untuk dikonsumsi sebagai makanan tambahan atau sebagai bahan baku agroindustri pakan ternak (Antriyandarti \& Ani, 2017).

Usahatani jagung mempunyai adaptasi yang luas dan relatif mudah dibudidayakan sehingga komoditas ini ditanam oleh petani pada lingkungan fisik dan sosial ekonomi yang sangat beragam, hal ini juga didukung oleh tersedianya lahan yang disediakan perusahaan sebagai upaya tindakan pencegahan kebakaran lahan dan dukungan sarana produksi untuk usahatani jagung seperti pupuk dolomit dan NPK, benih unggul, dan pestisida. Dilihat dari peluangnya, Kabupaten Sanggau saat ini lebih fokus mengembangkan pertanian pangan khususnya komoditi jagung di tahun 2020, disebabkan karena saat ini permintaan akan jagung cukup tinggi dengan pangsa pasar yang akan dituju yaitu kota Singkawang dan negara Malaysia. Penelitian Antriyandarti \& Ani (2017) mengatakan usahatani jagung menguntungkan bagi petani yang memproduksi dan masyarakat secara keseluruhan. 
Adanya CSR melalui program DMPA tersebut, diharapkan masyarakat lokal tidak lagi menjalankan pola pertanian secara berpindah-pindah dan hal ini dapat mencegah terjadinya kebakaran lahan. Maka dari itu kewajiban perusahaan untuk melaksanakan CSR dapat terlaksana sehingga kontinuitas perusahaan tetap terjaga dan dapat meningkatkan pendapatan masyarakat setempat. Berbeda dengan penelitian Saharjo \& Waldi (2019) strategi pengendalian kebakaran hutan yang diterapkan hanya mencakup kegiatan pencegahan, pemadaman dan penanganan pasca kebakaran hutan serta memperbanyak upaya peningkatan keahlian anggota Masyarakat Peduli Api (MPA), sementara penelitian ini untuk menyusun strategi dalam meningkatkan kinerja Corporate Social Responsibility (CSR) melalui program Desa Makmur Peduli Api (DMPA) di bidang pertanian pangan khususnya usahatani jagung oleh PT Finnantara Intiga Di Kabupaten Sanggau, dalam usaha mencegah kebakaran lahan.

\section{METODE PENELITIAN}

Penelitian dilaksanakan di Desa Mengkiang Kecamatan Kapuas Kabupaten Sanggau Provinsi Kalimantan Barat, merupakan area di sekitar PT. Finantara Intiga, lokasi program DMPA. Metode penelitian ini menggunakan metode deskriptif. Teknik pengumpulan data menggunakan teknik survei dan data yang dihasilkan berupa data primer dan data sekunder. Data primer dikumpulkan sendiri oleh peneliti melalui wawancara, data tersebut berupa hasil jawaban dari responden atas pertanyaan yang diajukan oleh peneliti dengan menggunakan kuesioner. Data sekunder didapat dari laporan program Corporate Social Responsibility yang diberikan perusahaan, internet, buku, jurnal, dan studi literatur yang terkait dengan penelitian. Responden dari penelitian ini dibagi menjadi dua jenis yaitu informan kunci (key informan) sebanyak 4 orang dan informan biasa sebanyak 18 orang. Metode penentuan responden menggunakan nonprobalility sampling dengan penentuan sampel secara purposive sampling. Purposive adalah pengambilan sampel dilakukan secara sengaja atas dasar pertimbangan peneliti (Sugiyono, 2017). Variabel penelitian diperoleh dari indikator-indikator kekuatan (strength), kelemahan (weakness), peluang (opportunity), dan ancaman (threats) usahatani jagung. Identifikasi Indikator SWOT diperoleh melalui studi pustaka, kajian literatur, riset eksploratif dan wawancara mendalam dengan menggunakan metode Delphi, yaitu metode pengumpulan data berdasarkan pendapat para pakar dengan instrumen kuesioner secara panel.

Penelitian ini menggunakan dua tahap metode analisis data. Tahap pertama adalah analisis SWOT, analisis ini menggunakan dasar logika memaksimalkan kekuatan dan peluang. Namun secara bersamaan juga meminimalkan kelemahan dan ancaman (Rangkuti, 2018). Analisis SWOT dilakukan dengan cara mengidentifikasi kondisi internal dan kondisi eksternal yang akan dijadikan indikator SWOT sebagai dasar merancang strategi dalam meningkatkan kinerja Corporate Social Responsibility melalui program Desa Makmur Peduli Api (DMPA) di bidang pertanian pangan, khususnya usahatani jagung. Indikator-indikator SWOT yang telah diketahui, ditentukan bobot, rating, dan skor untuk mengetahui kondisi internal dan eksternal program DMPA di bidang pertanian pangan khususnya pada usahatani jagung melalui matriks IFAS dan EFAS. Kemudian dianalisis menggunakan matrik posisi menggunakan rumus $\mathrm{S}-\mathrm{W}$ (selisih antara strengths dengan weakness) sebagai sumbu X (kuadran strategi) dan $\mathrm{O}-$ $\mathrm{T}$ (selisih antara opportunities dengan threats) sebagai sumbu Y (kuadran strategi), matrik ini digunakan untuk melihat posisi strategi peningkatan kinerja CSR melalui program DMPA pada usahatani jagung. Selanjutnya merumuskan alternatif strategi yang 
diperlukan dengan menggunakan matrik SWOT, hasil analisis matriks SWOT menunjukan beberapa strategi alternatif yang akan diimplementasikan. Tahap kedua adalah analisis Quantitative Strategic Planning Matrix (QSPM) yang digunakan untuk mengevaluasi strategi alternatif secara obyektif berdasarkan faktor-faktor sukses utama internal dan eksternal yang telah diidentifikasikan pada tahap analisis SWOT (David, 2016). Hasil analisis QSPM yang menjadi prioritas utama akan dijadikan sebagai strategi alternalif dalam peningkatan kinerja CSR melalui program DMPA pada usahatani jagung, sehingga dapat meningkatkan kesejahteraan petani. Berikut kerangka pemikiran dalam penelitin ini.

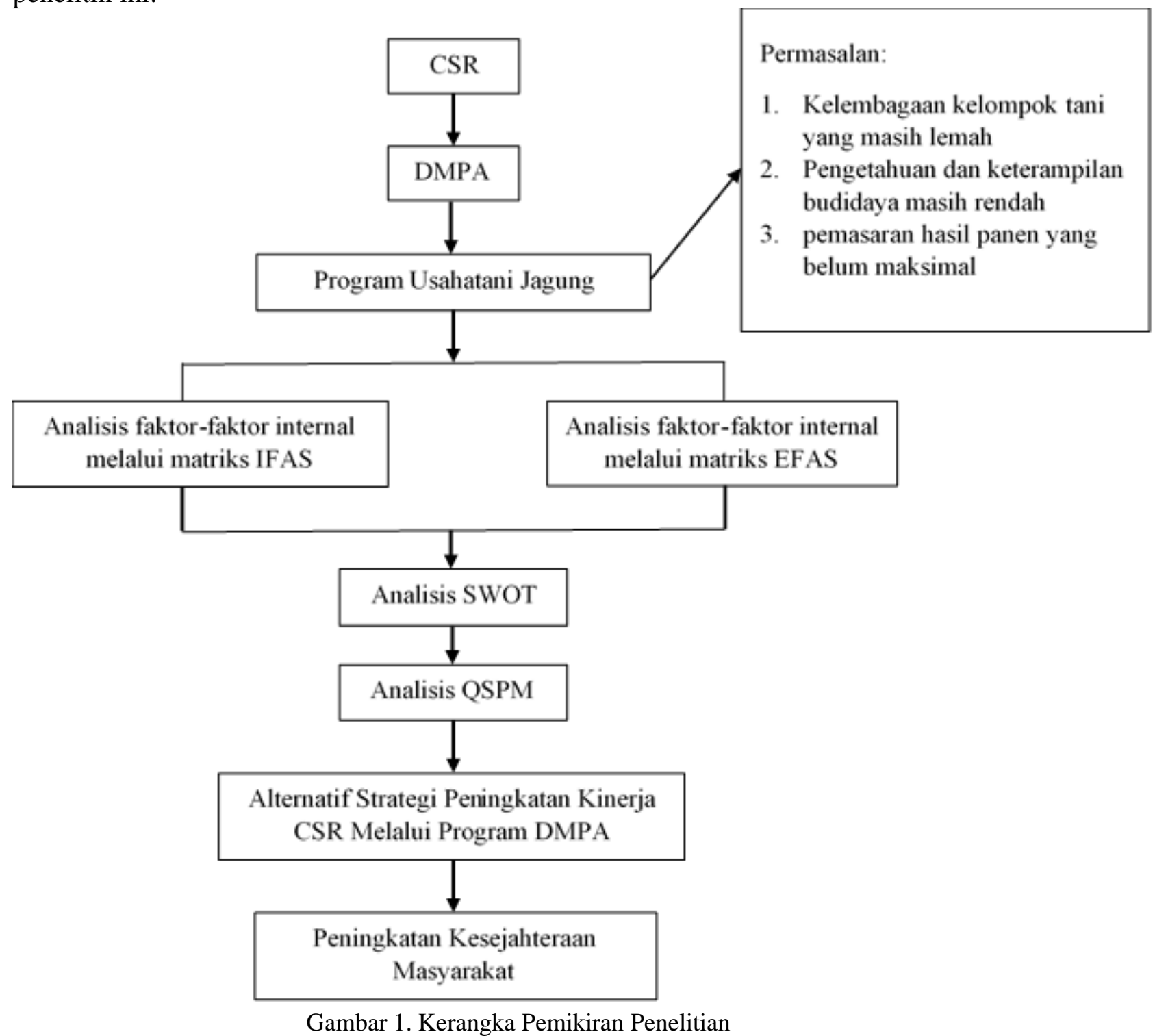

Sumber: Data Primer Diolah, 2020

\section{HASIL DAN PEMBAHASAN}

Pelaksanaan Corporate Social Responsibility (CSR) Melalui Program Desa Makmur Peduli Api (DMPA)

PT Finnantara Intiga menggunakan istilah CD (Community Development) dalam program-program tanggung jawab perusahaannya. Corporate Social Responsibility (CSR) tersebut berupa kemitraan perusahaan dengan masyarakat. Model CSR yang 
diterapkan oleh perusahaan yaitu keterlibatan langsung, dengan menyelenggarakan sendiri kegiatan sosial atau menyerahkan bantuan usahatani ke masyarakat tanpa perantara, seperti pemberian pupuk dolomit, pupuk NPK sebanyak $300 \mathrm{~kg} / \mathrm{ha}$, benih jagung unggul Bima 20 sebanyak $15 \mathrm{~kg} / \mathrm{ha}$, dan pestisida. Pelaksanaan CSR tersebut menggunakan dana perusahaan yang tertuang dalam Peraturan Daerah Provinsi Kalimantan Barat Nomor 4 tahun 2016 tentang Pengelolaan Tanggung Jawab Sosial dan Bina Lingkungan Perusahaan (TSBLP) sebesar 2,5\% dari keuntungan perusahaan per tahun berdasarkan audit yang dilakukan oleh akuntan publik. Bentuk CSR yang dijalankan perusahaan yaitu program Desa Makmur Peduli Api (DMPA).

DMPA merupakan bentuk program pemberdayaan masyarakat untuk mencegah kebakaran hutan dan lahan, serta peningkatan ekonomi masyarakat berbasisis pertanian. Program ini juga sejalan dengan upaya pemerintah, dalam peningkatan berbagai inovasi sebagai wujud komitmen terhadap tercapainya Sustainable Development Goal's (SDG). Adapun program DMPA ini dilaksanakan secara bertahap sesuai dengan kondisi dan potensi dari desa-desa yang menjadi sasaran program, antara lain:

1. Pemberdayaan Ekonomi Masyarakat di bidang pertanian untuk meningkatkan perekonomian rakyat.

2. Kemitraan Pemasaran Produk yaitu membantu masyarakat memasarkan hasil produk sumberdaya (budidaya pertanian, peternakan dan lain sebagainya).

3. Bertanggung jawab dalam mencegah potensi terjadinya kebakaran di sekitar desa.

Jenis program pemberdayaan DMPA yang dijalankan, seperti di bidang pertanian pangan (padi dan jagung), peternakan (sapi), dan perikanan (nila dan lele). Dalam hal ini PT Finnantara Intiga dan masyarakat telah menyepakati bahwa komoditas tanaman yang sesuai dengan kondisi lingkungan desa Mengkiang adalah komoditas tanaman pangan yaitu jagung.

\section{Karakteristik Usahatani Jagung Di Desa Mengkiang}

Perusahaan menyediakan lahan untuk berusahatani jagung rata-rata seluas 1,8 hektar per kelompok tani. Jenis jagung yang dikembangkan adalah jagung hibrida. Jagung hibrida termasuk komoditi yang mudah dalam perawatan, umurnya pun sekitar 3,5 bulan. Petani yang berada di sekitar areal konsesi perusahaan telah bergabung dalam kelompok tani, namun tidak semua anggota kelompok tani berperan aktif dalam usahatani jagung yang dijalankan, hal ini disebabkan oleh kurangnya motivasi kelompok tani untuk mengembangkan usahatani jagung. Rendahnya motivasi petani terhadap usahatani jagung di desa mengkiang menyebabkan petani berpindah ke komoditas lain. Selain itu, pengetahuan dan keterampilan usahatani jagung masih rendah, dikarenakan peran penyuluh atau PPL belum berkontribusi maksimal dalam memberikan pengarahan, pembinaan, dan penyuluhan mengenai usahatani jagung.

Usahatani jagung dimulai dari persiapan lahan dengan cara tebas dan penyemprotan gulma, selanjutnya pemberian pupuk dolomit sebagai pupuk dasar. Teknik penanaman benih jagung dilakukan dengan sistem tugal atau tumbuk baris jajar dengan jarak tanam sebesar 40x70 cm. Petani melakukan pemupukan setelah jagung berumur 5 hari setelah tanam dan 30 hari setelah tanam menggunakan pupuk NPK 15-15-15 untuk membantu pertumbuhan tanaman agar berkembang secara maksimal. Pemupukan dengan cara tugal disamping tanaman jagung dengan jarak $10 \mathrm{~cm}$. Pupuk NPK yang digunakan rata-rata $200 \mathrm{~kg} / \mathrm{ha}$, sedangkan dosis tepat penggunaan pupuk NPK pada tanaman jagung adalah $300 \mathrm{~kg} / \mathrm{ha}$ (Pusparini et al., 2018). Pembumbunan dilakukan pada saat umur tanaman 25-30 hari setelah tanam. Pengendalian gulma dilakukan secara manual pada 
saat umur tanaman 15-20 hari dan 30-35 hari setelah tanam. Jagung dipanen setelah berumur \pm 90 hari. Namun hasil panen yang didapatkan belum maksimal yaitu sebesar \pm 2,2 ton/ha, sedangkan benih unggul jagung yang digunakan mempunyai potensi hasil produksi tinggi jika dipadu dengan manajemen produksi yang baik maka hasil produksi jagung dapat mencapai 8-9 ton/ha.

Harga perkilo jangung hibrida mencapai Rp 5000-Rp 6000. Pemasaran hasil produksi jagung belum maksimal, karena keterbatasan informasi pasar yang diterima petani, sehingga saat ini petani menjual hasil panennya secara individu dengan membawa jagung yang sudah kering giling ke pasar atau di sekitaran kampung. Penjualan secara individu juga menjadi kendala untuk melakukan kerjasama pemasaran dengan pengolah jagung karena ketidakmampuan petani menyediakan jagung dalam kuantitas dan kualitas sesuai permintaan industri pengolah jagung.

\section{Analisis SWOT}

Analisis SWOT dilakukan dengan cara mengidentifikasi faktor internal dan eksternal. Kemudian ditentukan bobot, rating dan skor untuk mengetahui kondisi internal dan eksternal program Desa Makmur Peduli Api (DMPA) di bidang pertanian pangan khususnya usahatani jagung melalui matriks IFAS dan EFAS.

Faktor internal merupakan faktor yang mempengaruhi lingkungan dalam perusahaan untuk merumuskan strategi peningkatan kinerja Corporate Social Responsibility (CSR) melalui program Desa Makmur Peduli Api (DMPA) di bidang pertanian pangan khususnya usahatani jagung oleh PT. Finnantara Intiga di Kabupaten Sanggau terdiri dari kekuatan (strengts) dan kelemahan (weakness), yaitu:

1. Faktor kekuatan (strengts)

a. Lahan disediakan oleh perusahaan

b. Mudah untuk dibudidayakan

c. Petani telah menggunakan benih unggul

d. Sarana produksi disediakan oleh perusahaan

e. Mencegah kebakaran lahan di sekitar desa

2. Faktor kelemahan (weakness)

a. Pupuk yang diberikan tidak tepat sasaran

b. Produksi jagung yang rendah

c. Penyuluh pertanian belum berkontribusi maksimal

d. Kemampuan manajerial petani yang lemah

e. Kelompok tani belum berperan optimal dalam pemasaran

f. Anggota kelompok tani tidak aktif

g. Motivasi petani rendah

h. Kurang maksimalnya pengawasan program Desa Makmur Peduli Api (DMPA)

Faktor eksternal merupakan faktor yang mempengaruhi lingkungan luar perusahaan dalam strategi meningkatkan kinerja Corporate Social Responsibility (CSR) melalui program Desa Makmur Peduli Api (DMPA) di bidang pertanian pangan khususnya usahatani jagung oleh PT. Finnantara Intiga di Kabupaten Sanggau terdiri dari peluang (opportunity) dan ancaman (threats), yaitu:

1. Faktor peluang (opportunity)

a. Permintaan jagung di Kabupaten Sanggau yang tinggi

b. Akses infrastruktur jalan baik

c. Adanya dukungan pemerintah berupa bantuan alat pasca panen (mesin pipil jagung) 
d. Semakin banyak produk turunan jagung yang berkembang

e. Peluang pasar ke luar daerah (ekspor)

f. Pengembangan jagung jadi prioritas pemerintah daerah

g. Hubungan masyarakat dengan perusahaan yang baik

2. Faktor ancaman (threats)

a. Komoditas padi yang menjadi pesaing utama dalam tanaman pangan

b. Kondisi cuaca yang buruk

c. Adanya pandemi covid-19

d. Jaringan pasar rendah

Setelah mengetahui faktor-faktor internal dan eksternal dalam strategi meningkatkan kinerja Corporate Social Responsibility (CSR) melalui program Desa Makmur Peduli Api (DMPA) pada usahatani jagung, tahapan selanjutnya adalah menyusun dan menghitungnya pada matrik IFAS (internal strategic factor analisis summary) dan matrik EFAS (eksternal strategic factor analisis summary). Berikut ini adalah matrik IFAS dan EFAS yang berpengaruh terhadap usahatani jagung dalam program DMPA.

Tabel 1. Matrik IFAS

\begin{tabular}{|c|c|c|c|c|}
\hline No. & FAKTOR KEKUATAN & BOBOT & RATING & SKOR \\
\hline IND 1 & Lahan disediakan oleh perusahaan & 0.069 & 3.50 & 0.242 \\
\hline IND 2 & Mudah untuk dibudidayakan & 0.072 & 2.50 & 0.180 \\
\hline IND 3 & Petani telah menggunakan benih unggul & 0.087 & 3.25 & 0.284 \\
\hline IND 4 & Sarana produksi disediakan oleh perusahaan & 0.087 & 3.25 & 0.284 \\
\hline IND 5 & Mencegah kebakaran lahan di sekitar desa & 0.077 & 3.00 & 0.231 \\
\hline \multicolumn{2}{|r|}{ TOTAL } & \multicolumn{3}{|r|}{1,221} \\
\hline & FAKTOR KELEMAHAN & BOBOT & RATING & SKOR \\
\hline IND 1 & Pupuk yang diberikan tidak tepat sasaran & 0.077 & 1.75 & 0.135 \\
\hline IND 2 & Produksi jagung rendah & 0.082 & 2.25 & 0.185 \\
\hline IND 3 & Penyuluh pertanian belum berkontribusi maksimal & 0.076 & 2.25 & 0.171 \\
\hline IND 4 & Kemampuan manajerial petani yang lemah & 0.072 & 2.50 & 0.180 \\
\hline IND 5 & $\begin{array}{l}\text { Kelompok tani belum berperan optimal dalam } \\
\text { pemasaran }\end{array}$ & 0.074 & 2.25 & 0.167 \\
\hline IND 6 & Anggota kelompok tani tidak aktif & 0.075 & 2.25 & 0.169 \\
\hline IND 7 & Motivasi petani rendah & 0.072 & 2.50 & 0.180 \\
\hline IND 8 & $\begin{array}{l}\text { Kurangnya pengawasan program DMPA kepada } \\
\text { masyarakat yang mendapatkan bantuan }\end{array}$ & 0.078 & 2.00 & 0.156 \\
\hline & TOTAL & $\mathbf{1 , 0 0 0}$ & & 1,344 \\
\hline
\end{tabular}

Sumber: Data Primer Diolah, 2020

Tabel 1 menunjukkan bahwa faktor kekuatan memiliki pengaruh besar terhadap penggunaan benih unggul dan sarana produksi yang disediakan oleh perusahaan dengan nilai skor 0,284 . Penggunaan benih unggul berperan dalam meningkatkan produktivitas usahatani jagung. Hal ini serupa dengan penelitian Haryati \& Anna (2016). Diikuti sarana produksi yang disediakan oleh perusahaan seperti benih, pupuk, dan pestisida. Hal ini sejalan dengan penelitian (Salatan et al., 2018) yang menyatakan bahwa pemberian bantuan sapras penunjang usahatani jagung sangat mempengaruhi berkembangnya usahatani jagung. Sedangkan faktor kelemahan yang mempunyai pengaruh besar adalah produksi jagung yang rendah dengan nilai skor 0,185 . Faktor rendahnya produksi jagung, dikarenakan tingkat motivasi petani rendah, kemampuan manajerial petani yang lemah dan penggunaan input produksi kurang optimal di daerah penelitian, sehingga keuntungan petani rendah dan memberikan hasil yang belum maksimal. Hal ini juga di perkuat Yusuf et al. (2014) yang mengemukakan bahwa luas lahan, pupuk, tenaga kerja, pestisida, bibit, dan iklim mempengaruhi produksi jagung. 
Nilai total faktor strategis kekuatan lebih kecil dibandingkan faktor strategis kelemahan. Hal ini berarti, seberapa besar kemampuan petani jagung dalam mengatasi kelemahan yang cukup besar secara bersamaan juga memanfaatkan kekuatan yang ada dalam usahatani jagung di daerah tersebut. Hasil analisis pada tabel 1 , menunjukkan nilsi selisih antara faktor kekuatan dan faktor kelemahan dengan nilai sebesar -0,123 dibulatkan menjadi -0,12 dan dijadikan sebagai sumbu X.

Tabel 2. Matrik EFAS

\begin{tabular}{|c|c|c|c|c|}
\hline No. & FAKTOR PELUANG & BOBOT & RATING & SKOR \\
\hline IND 1 & Permintaan jagung di Kabupaten Sanggau tinggi & 0.093 & 3.25 & 0.304 \\
\hline IND 2 & Akses infrastruktur jalan baik & 0.096 & 2.75 & 0.264 \\
\hline IND 3 & $\begin{array}{l}\text { Adanya dukungan pemerintah berupa bantuan alat pasca } \\
\text { panen (mesin pipil) }\end{array}$ & 0.090 & 3.25 & 0.292 \\
\hline IND 4 & Semakin banyak produk turunan jagung yang berkembang & 0.085 & 2.25 & 0.191 \\
\hline IND 5 & Peluang pasar ke luar daerah (ekspor) & 0.091 & 3.25 & 0.296 \\
\hline IND 6 & Pengembangan jagung jadi prioritas pemerintah daerah & 0.089 & 2.25 & 0.199 \\
\hline IND 7 & Hubungan masyarakat dengan perusahaan yang baik & 0.097 & 3.00 & 0.291 \\
\hline & $\begin{array}{ll}\text { TOTAL } \\
\end{array}$ & & & $\mathbf{1 , 8 3 7}$ \\
\hline & FAKTOR ANCAMAN & BOBOT & RATING & SKOR \\
\hline IND 1 & $\begin{array}{l}\text { Komoditas padi yang menjadi pesaing utama dalam } \\
\text { tanaman pangan }\end{array}$ & 0.087 & 3.00 & 0.262 \\
\hline IND 2 & $\begin{array}{l}\text { Kondisi cuaca yang buruk dan rawan menimbulkan } \\
\text { bencana (banjir/kemarau) }\end{array}$ & 0.090 & 2.50 & 0.225 \\
\hline IND 3 & $\begin{array}{l}\text { Adanya pandemi covid-19 yang mengakibatkan bisnis } \\
\text { sektor pangan melemah khususnya jagung yang } \\
\text { menyebabkan daya serap jagung rendah }\end{array}$ & 0.089 & 2.75 & 0.244 \\
\hline IND 4 & Jaringan pasar rendah & 0.093 & 4.00 & 0.374 \\
\hline & TOTAL & & & 1,104 \\
\hline
\end{tabular}

Tabel 2 menunjukkan bahwa faktor strategis peluang mempunyai pengaruh besar terhadap permintaan jagung yang tinggi di Kabupaten Sanggau dengan nilai skor 0,304. Hal ini di perkuat Sidabutar et al. (2014) yang menyatakan bahwa pertumbuhan jumlah penduduk dan perkembangan sektor industri menyebabkan permintaan bahan baku jagung terus meningkat. Hal tersebut menjadi peluang besar bagi masyarakat sekitar untuk berusahatani jagung karena permintaan jagung sangat tinggi. Sedangkan dari keempat faktor strategis ancaman yang paling berpengaruh adalah jaringan pasar yang rendah dengan nilai skor 0,374. Perluasan jaringan pasar dilakukan dengan cara melibatkan kelompok tani dalam proses pemasaran. Kerja sama kelompok tani dengan perusahaan pengolahan jagung merupakan salah satu cara membuka jaringan pemasaran seperti pabrik pakan ternak maupun olahan jagung yang lain. Sejalan dengan penelitian Rahayu et al. (2020) yang menyatakan pemasaran yang dilakukan berkelompok akan sangat memudahkan petani untuk mendapatkan informasi pasar sehingga jangkauan pemasaran akan semakin luas.

Nilai total faktor strategis peluang lebih besar dibandingkan nilai total faktor strategis ancaman, hal ini menunjukkan bahwa program usahatani jagung bagus untuk dibudidayakan dan mempunyai peluang besar jika dikelola dengan maksimal. Hasil analisis pada Tabel 2, menunjukkan selisih antara faktor peluang dan faktor ancaman mempunyai nilai sebesar 0,733 dibulatkan menjadi 0,73 dan dijadikan sebagai sumbu Y.

Berdasarkan nilai selisih yang didapatkan dari hasil analisis IFAS dan EFAS yang selanjutnya diuraikan dalam diagram analisis SWOT seperti pada Gambar 1. 


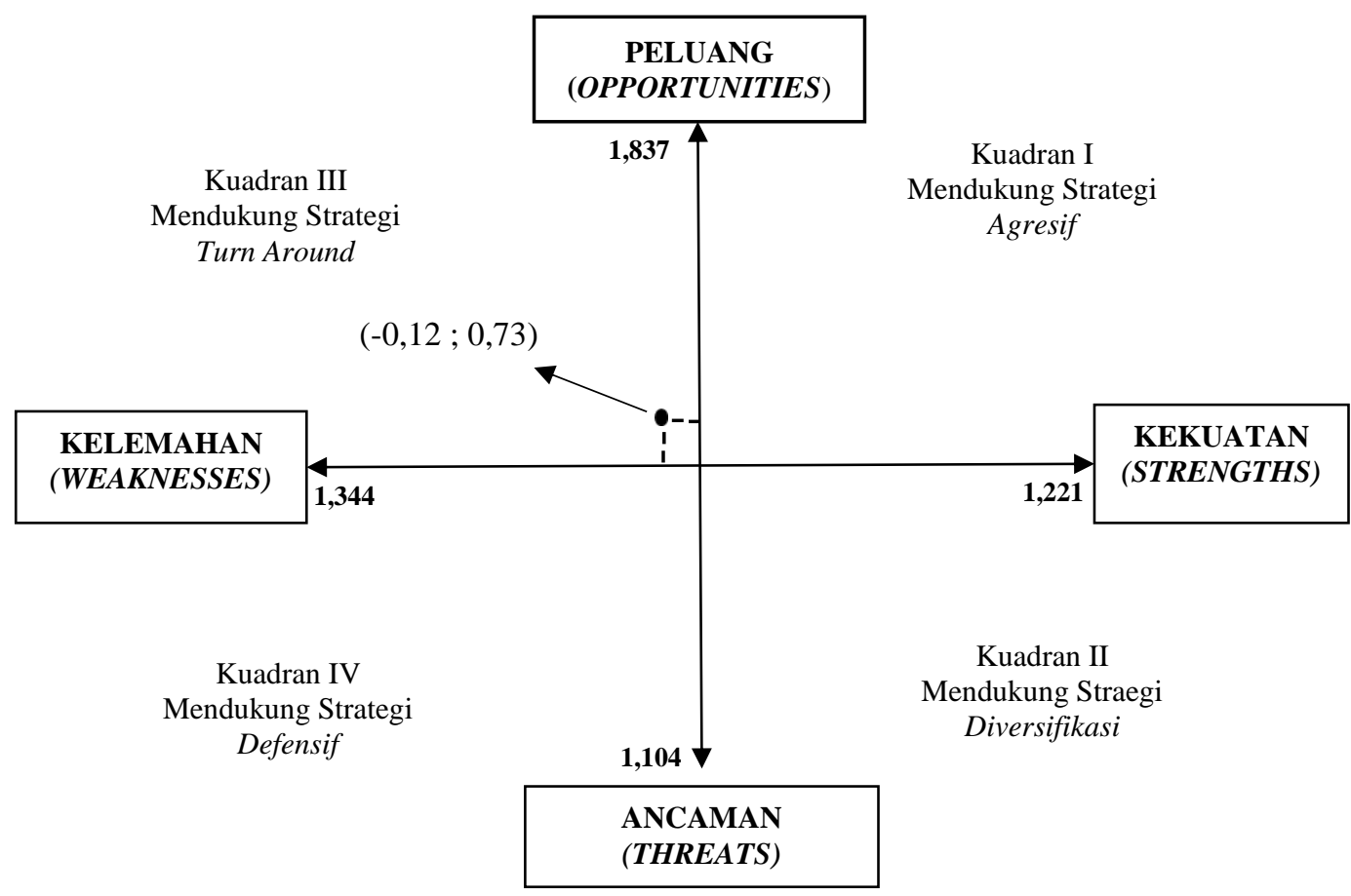

Gambar 2. Posisi Strategi Peningkatan Kinerja CSR melalui DMPA di Bidang Pertanian Pangan Khususnya Usahatani Jagung

Sumber: Data Primer Diolah, 2020

Gambar 2. menunjukkan bahwa strategi peningkatan kinerja CSR melalui DMPA di bidang pertanian pangan khususnya usahatani jagung berada pada posisi kuadran 3 , karena memiliki nilai total faktor strategis yang paling besar yaitu faktor kelemahan (Weakness) dan faktor peluang (Opportunities), artinya program usahatani jagung menghadapi kendala/kelemahan yang berasal dari lingkungan internal. Namun disisi lain menghadapi peluang yang cukup besar. Pada kondisi ini strategi WO (Weakness dan Opportunities) digunakan dengan cara meminimalkan kelemahan agar dapat merebut pasar yang lebih baik. Posisi ini menandakan suatu kegiatan usahatani jagung yang lemah namun sangat berpeluang. Strategi yang harus diterapkan dalam kondisi ini adalah mendukung strategi turn around, yaitu dengan meminimalkan masalah-masalah internal perusahaan sehingga dapat merebut peluang pasar yang lebih besar, atau dengan cara mengubah strategi, artinya perusahaan disarankan untuk mengubah strategi sebelumnya.

Berdasarkan matrik IFAS dan EFAS serta diagram analisis SWOT, maka dapat dirumuskan asumsi-asumsi strategi yang dapat dilihat pada Tabel 3. 
Tabel 3. Matrik SWOT

\begin{tabular}{|c|c|c|}
\hline Faktor Eksternal & $\begin{array}{l}\text { Kekuatan (Strengths) } \\
\text { 1. Lahan disediakan oleh perusahaan } \\
\text { 2. Mudah untuk dibudidayakan } \\
\text { 3. Petani telah menggunakan benih } \\
\text { unggul } \\
\text { 4. Sarana produksi disediakan oleh } \\
\text { perusahaan } \\
\text { 5. Mencegah kebakaran lahan di } \\
\text { sekitar desa }\end{array}$ & $\begin{array}{l}\text { Kelamahan (Weakness) } \\
\text { 1. Pupuk yang diberikan tidak } \\
\text { tepat sasaran } \\
\text { 2. Produksi jagung Rendah } \\
\text { 3. Penyuluh pertanian belum } \\
\text { berkontribusi maksimal } \\
\text { 4. Kemampuan manajerial } \\
\text { petani yang lemah } \\
\text { 5. Kelompok tani belum } \\
\text { berperan optimal dalam } \\
\text { pemasaran } \\
\text { 6. Anggota kelompok tani } \\
\text { tidak aktif } \\
\text { 7. Motivasi petani rendah } \\
\text { 8. Kurangnya pengawasan } \\
\text { program DMPA kepada } \\
\text { masyarakat yang } \\
\text { mendapatkan bantuan }\end{array}$ \\
\hline Peluang (Opportunities) & Strategi S-O & Strategi W-O \\
\hline $\begin{array}{l}\text { 1. Permintaan jagung di } \\
\text { Kabupaten Sanggau yang } \\
\text { tinggi } \\
\text { 2. Akses infrastruktur jalan } \\
\text { baik } \\
\text { 3. Adanya dukungan } \\
\text { pemerintah berupa bantuan } \\
\text { alat pasca panen (mesin } \\
\text { pipil) } \\
\text { 4. Semakin banyak produk } \\
\text { turunan jagung yang } \\
\text { berkembang } \\
\text { 5. Peluang pasar ke luar daerah } \\
\text { (ekspor) } \\
\text { 6. Pengembangan jagung jadi } \\
\text { prioritas pemerintah daerah } \\
\text { 7. Hubungan masyarakat } \\
\text { dengan perusahaan yang } \\
\text { baik }\end{array}$ & $\begin{array}{l}\text { 1. Penerapan budidaya jagung yang } \\
\text { baik dengan pendekatan } \\
\text { pengelolaan tanaman secara } \\
\text { terpadu (PTT) (S3, S5, O5) } \\
\text { 2. Melakukan intensifikasi dan } \\
\text { ekstensifikasi lahan untuk jagung } \\
\text { (S1, O1, O7) } \\
\text { 3. Meningkatkan nilai tambah produk } \\
\text { (S2, O2, O3, O4) } \\
\text { 4. Kelompok tani dan pemerintah } \\
\text { bekerja sama membuat pembinaan } \\
\text { bersama (S2, O6) }\end{array}$ & 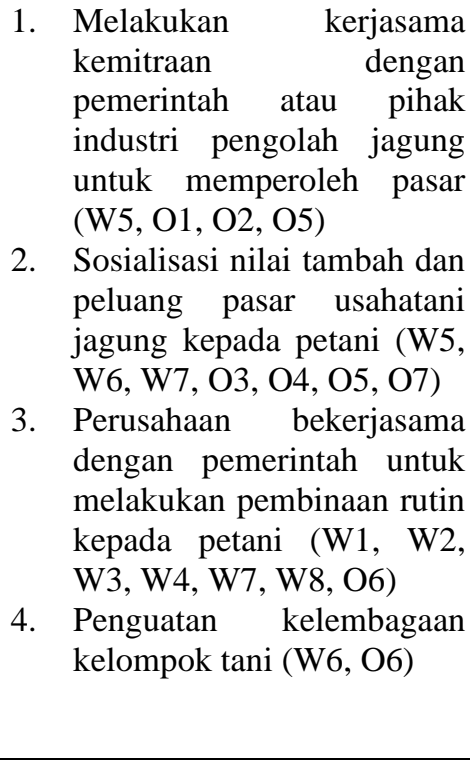 \\
\hline Ancaman (Threats) & Strategi S-T & Strategi W-T \\
\hline $\begin{array}{l}\text { 1. Komoditas padi yang } \\
\text { menjadi pesaing utama } \\
\text { dalam tanaman pangan } \\
\text { 2. Kondisi cuaca yang buruk } \\
\text { dan rawan menimbulkan } \\
\text { bencana (banjir/kemarau) } \\
\text { 3. Adanya pandemi covid-19 } \\
\text { yang mengakibatkan bisnis } \\
\text { sektor pangan melemah } \\
\text { khususnya jagung yang } \\
\text { menyebabkan daya serap } \\
\text { jagung rendah } \\
\text { 4. Jaringan pasar rendah }\end{array}$ & 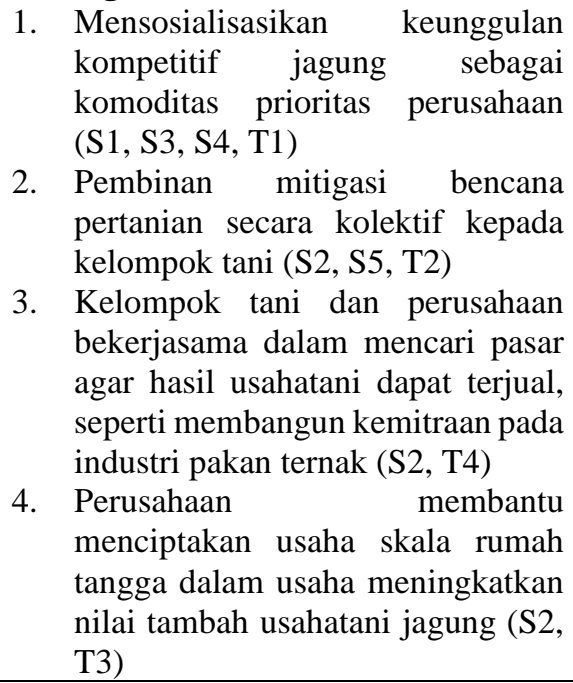 & $\begin{array}{ll}\text { 1. } & \begin{array}{l}\text { Sosialisasikan peluang } \\
\text { ekonomi komoditas jagung }\end{array} \\
\text { dibandingkan komoditas } \\
\text { lain (W7, W8, T1) } \\
\text { 2. } \begin{array}{l}\text { Perusahaan membina petani } \\
\text { terkait mitigasi bencana }\end{array} \\
\text { (W3, T2) } \\
\text { 3. Perusahaan membina } \\
\text { kelompok tani untu mencari } \\
\text { pasar (W5, W6, T3, T4) } \\
\text { 4. Pelatihan inovasi teknologi } \\
\text { pertanian melalui sekolah } \\
\text { lapang (W2, W7, T1) } \\
\text { 5. Mengedukasi petani terkait } \\
\text { manajerial usahatani (W1, } \\
\text { W4, T1) }\end{array}$ \\
\hline
\end{tabular}

Sumber: Data Primer Diolah, 2020 
Berdasarkan hasil perhitungan matriks IFAS dan matriks EFAS sebagai acuan untuk menentukan alternatif strategi, maka diperoleh strategi WO (Weakness dan Opportunities) karena kedua faktor tersebut memiliki skor tertinggi. Strategi tersebut bertujuan untuk memperkecil kelemahan-kelemahan internal perusahaan dengan memanfaatkan peluang-peluang eksternal perusahaan (Rangkuti, 2018). Adapun beberapa alternatif strategi WO (Weakness dan Opportunities) yang dapat dipertimbangkan antara lain:

1. Melakukan kerjasama atau kemitraan dengan pihak industri pengolah jagung atau pemerintah untuk memperoleh pasar

Salah satu upaya penting dalam mengembangkan usahatani jagung adalah dengan strategi perluasan pemasaran jagung. Perluasan pasar akan mendorong petani untuk mengembangkan usahatani jagung dalam memenuhi permintaan pasar (Rahayu et al., 2020). Perluasan jaringan pemasaran dapat dilakukan dengan cara meningkatkan peran kelompok tani dalam pemasaran. Hal ini sejalan dengan penelitian Anwar (2019) yang mengatakan bahwa dengan adanya kelompok tani sebagai wadah komunikasi dan pembinaan bagi petani, serta memudahkan petani untuk membuka akses ataupun peluang kerjasama dengan lembaga-lembaga yang mampu menampung hasil produksi petani dan menjaga kestabilan harga jagung. Dengan demikian, upaya yang dapat dilakukan adalah dengan cara meningkatkan peran kelompok tani dalam memasarkan jagung secara berkelompok sehingga petani memiliki posisi yang kuat di pasar.

2. Sosialisasi nilai tambah dan peluang pasar usahatani jagung kepada petani

Mengadakan sosialisasi kepada petani agar memanfaatkan tingginya nilai tambah jagung dengan cara mengusahakan berbagai macam jenis produk olahan makanan berbahan baku jagung. Hal ini dapat menjadi peluang besar bagi petani untuk menambah pendapatan petani jagung. Maka hal tersebut dapat mendorong petani untuk meningkatkan produksi dan kualitas jagung dalam memenuhi permintaan pasar, dengan cara petani lebih giat berusaha tani, menerapkan fungsi manajerial usahatani dan mengadopsi teknologi baru, sehingga dapat berkontribusi terhadap peningkatan kesejahteraan petani jagung.

3. Perusahaan bekerjasama dengan pemerintah untuk melakukan pembinaan rutin kepada petani

Perusahaan dapat bekerjasama dengan pemerintah dalam melakukan pembinaan kepada petani, dengan cara meningkatkan kinerja PPL untuk selalu aktif membina kelompok tani dengan memanfaatkan lahan dan sarana produksi yang telah diberikan perusahaan untuk berusahatani jagung, sehingga dapat memenuhi permintaan pasar dan meningkatkan kualitas sumberdaya manusia. Sejalan dengan penelitian Anwar (2019) yang mengatakan bahwa peningkatan kemampuan petani dalam manajemen usahatani jagung melalui pembinaan yang dilakukan PPL dan lembaga swasta sangat penting, guna mengatasi persoalan persaingan harga dengan komoditi lain, dapat merencanakan usahatani jagung lebih baik dan memiliki kemampuan serta wawasan agribisnis jagung.

Pembinaan kepada petani dilakukan dengan menjalankan program-program Sekolah Lapang Pengelolaan Tanaman Terpadu (SL-PTT), sehingga terciptanya tenaga kerja terampil untuk meraih peluang pasar dan mendapat manfaat dari tingginya nilai tambah usahatani jagung, serta mengadakan magang atau studi banding ke daerah sentra pengembangan tanaman jagung yang telah berkembang dan telah menggunakan teknologi budidaya jagung yang sesuai (Musna et al., 2016). 
4. Penguatan kelembagaan kelompok tani

Meningkatkan fungsi dan peran kelompok tani sebagai wadah komunikasi dan pemberdayaan petani dalam pengembangan usahatani jagung, dengan cara memotivasi petani agar menanam jagung sehingga tidak berpindah ke komoditas lain. Adanya kelompok tani membuat para petani dapat membagi ilmu dan saling bertukar pikiran kepada petani yang lain. Perbaikan kualitas sumber daya manusia (SDM) diharapkan mampu memberikan dampak positif terhadap kinerja petani (S. P. Nainggolan et al., 2014).

\section{Analisis Quantitive Strategic Planning Matrix (QSPM).}

Berdasarkan matriks SWOT menunjukan strategi alternatif yang diimplementasikan adalah strategi WO (Weakness dan Opportunities). Selanjutnya, penentuan prioritas strategi yang paling tepat dalam meningkatkan kinerja Corporate Social Responsibility (CSR) melalui program Desa Makmur Peduli Api (DMPA) di bidang pertanian pangan khususnya usahatani jagung oleh PT Finnantara Intiga Di Kabupaten Sanggau, menggunakan QSPM. Pada matrik QSPM terdapat nilai AS (Attractiveness Score) yang menunjukan adanya daya tarik pada masing-masing strategi terhadap faktor kunci yang dimiliki dan nilai TAS merupakan hasil perkalian antara bobot rata-rata dengan nilai AS dari setiap faktor kunci strategi. Berikut adalah matrik QSPM hasil olahan data dapat dilihat pada tabel 4.

Tabel 4. Analisis Quantitative Strategy Planning Matrix (QSPM)

\begin{tabular}{|c|c|c|c|c|c|c|c|c|c|}
\hline \multirow{3}{*}{$\begin{array}{c}\begin{array}{c}\text { Faktor-faktor Strategis } \\
\text { QSPM }\end{array} \\
\text { Kekuatan }\end{array}$} & \multirow{3}{*}{ Bobot } & \multicolumn{8}{|c|}{ Alternatif Strategi } \\
\hline & & \multicolumn{2}{|c|}{ Strategi 1} & \multicolumn{2}{|c|}{ Strategi 2} & \multicolumn{2}{|c|}{ Strategi 3} & \multicolumn{2}{|c|}{ Strategi 4} \\
\hline & & AS & TAS & AS & TAS & AS & TAS & AS & TAS \\
\hline $\begin{array}{l}\text { 1. Lahan disediakan oleh } \\
\text { perusahaan }\end{array}$ & 0.069 & 3 & 0.207 & 4 & 0.276 & 4 & 0.276 & 4 & 0.276 \\
\hline $\begin{array}{l}\text { 2. Mudah untuk } \\
\text { dibudidayakan }\end{array}$ & 0.072 & 3 & 0.216 & 4 & 0.288 & 4 & 0.288 & 4 & 0.288 \\
\hline $\begin{array}{l}\text { 3. Petani telah menggunakan } \\
\text { benih unggul }\end{array}$ & 0.087 & 4 & 0.349 & 4 & 0.349 & 4 & 0.349 & 4 & 0.349 \\
\hline $\begin{array}{l}\text { 4. Sarana produksi disediakan } \\
\text { oleh perusahaan }\end{array}$ & 0.087 & 3 & 0.262 & 4 & 0.349 & 4 & 0.349 & 4 & 0.349 \\
\hline $\begin{array}{l}\text { 5. Mencegah kebakaran lahan } \\
\text { di sekitar desa }\end{array}$ & 0.077 & 4 & 0.309 & 4 & 0.309 & 4 & 0.309 & 4 & 0.309 \\
\hline \multicolumn{10}{|l|}{ Kelemahan } \\
\hline $\begin{array}{l}\text { 1. Pupuk yang diberikan tidak } \\
\text { tepat sasaran }\end{array}$ & 0.077 & 3 & 0.231 & 3 & 0.231 & 4 & 0.309 & 4 & 0.309 \\
\hline 2. Produksi jagung Rendah & 0.082 & 3 & 0.247 & 3 & 0.247 & 3 & 0.247 & 3 & 0.247 \\
\hline $\begin{array}{l}\text { 3. Penyuluh pertanian belum } \\
\text { berkontribusi maksimal }\end{array}$ & 0.076 & 2 & 0.152 & 2 & 0.152 & 3 & 0.228 & 2 & 0.152 \\
\hline $\begin{array}{l}\text { 4. Kemampuan manajerial } \\
\text { petani yang lemah }\end{array}$ & 0.072 & 3 & 0.216 & 3 & 0.216 & 4 & 0.288 & 4 & 0.288 \\
\hline $\begin{array}{l}\text { 5. Kelompok tani belum } \\
\text { berperan optimal dalam } \\
\text { pemasaran }\end{array}$ & 0.074 & 3 & 0.222 & 4 & 0.296 & 4 & 0.296 & 4 & 0.296 \\
\hline $\begin{array}{l}\text { 6. Anggota kelompok tani } \\
\text { tidak aktif }\end{array}$ & 0.075 & 3 & 0.225 & 3 & 0.225 & 4 & 0.301 & 4 & 0.301 \\
\hline 7. Motivasi petani rendah & 0.072 & 3 & 0.216 & 4 & 0.288 & 4 & 0.288 & 4 & 0.288 \\
\hline 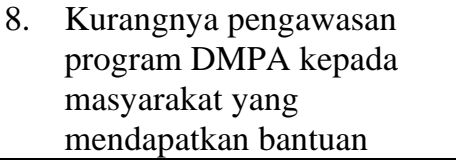 & 0.078 & 3 & 0.235 & 4 & 0.313 & 4 & 0.313 & 4 & 0.313 \\
\hline
\end{tabular}




\begin{tabular}{|c|c|c|c|c|c|c|c|c|c|}
\hline \multirow{2}{*}{$\begin{array}{c}\text { Faktor-faktor Strategis } \\
\text { QSPM }\end{array}$} & \multirow{2}{*}{ Bobot } & \multicolumn{8}{|c|}{ Alternatif Strategi } \\
\hline & & \multicolumn{2}{|c|}{ Strategi 1} & \multicolumn{2}{|c|}{ Strategi 2} & \multicolumn{2}{|c|}{ Strategi 3} & \multicolumn{2}{|c|}{ Strategi 4} \\
\hline \multicolumn{10}{|l|}{ Peluang } \\
\hline $\begin{array}{l}\text { 1. Permintaan jagung di } \\
\text { Kabupaten Sanggau yang } \\
\text { tinggi }\end{array}$ & 0.093 & 4 & 0.374 & 4 & 0.374 & 4 & 0.374 & 4 & 0.374 \\
\hline $\begin{array}{l}\text { 2. Akses infrastruktur jalan } \\
\text { baik }\end{array}$ & 0.096 & 3 & 0.288 & 3 & 0.288 & 3 & 0.288 & 2 & 0.192 \\
\hline $\begin{array}{l}\text { 3. Adanya dukungan } \\
\text { pemerintah berupa bantuan } \\
\text { alat pasca panen (mesin } \\
\text { pipil) }\end{array}$ & 0.090 & 3 & 0.269 & 3 & 0.269 & 4 & 0.359 & 3 & 0.269 \\
\hline $\begin{array}{l}\text { 4. Semakin banyak produk } \\
\text { turunan jagung yang } \\
\text { berkembang }\end{array}$ & 0.085 & 4 & 0.340 & 4 & 0.340 & 4 & 0.340 & 3 & 0.255 \\
\hline $\begin{array}{l}\text { 5. Peluang pasar ke luar } \\
\text { daerah (ekspor) }\end{array}$ & 0.091 & 3 & 0.273 & 3 & 0.273 & 3 & 0.273 & 3 & 0.273 \\
\hline $\begin{array}{l}\text { 6. Pengembangan jagung jadi } \\
\text { prioritas pemerintah daerah }\end{array}$ & 0.089 & 4 & 0.354 & 4 & 0.354 & 4 & 0.354 & 3 & 0.266 \\
\hline $\begin{array}{l}\text { 7. Hubungan masyarakat } \\
\text { dengan perusahaan yang } \\
\text { baik }\end{array}$ & 0.097 & 3 & 0.291 & 4 & 0.388 & 4 & 0.388 & 4 & 0.388 \\
\hline \multicolumn{10}{|l|}{ Ancaman } \\
\hline $\begin{array}{l}\text { Komoditas padi yang } \\
\text { menjadi pesaing utama } \\
\text { dalam tanaman pangan }\end{array}$ & 0.087 & 3 & 0.262 & 4 & 0.350 & 4 & 0.350 & 4 & 0.350 \\
\hline $\begin{array}{l}\text { 2. Kondisi cuaca yang buruk } \\
\text { dan rawan menimbulkan } \\
\text { bencana (banjir/kemarau) }\end{array}$ & 0.090 & 2 & 0.180 & 2 & 0.180 & 3 & 0.269 & 3 & 0.269 \\
\hline $\begin{array}{l}\text { 3. Adanya pandemi covid-19 } \\
\text { yang mengakibatkan bisnis } \\
\text { sektor pangan melemah } \\
\text { khususnya jagung yang } \\
\text { menyebabkan daya serap } \\
\text { jagung rendah }\end{array}$ & 0.089 & 3 & 0.266 & 4 & 0.354 & 3 & 0.266 & 4 & 0.354 \\
\hline 4. Jaringan pasar rendah & 0.093 & 3 & 0.280 & 4 & 0.374 & 3 & 0.280 & 3 & 0.280 \\
\hline Jumlah & & & 6.266 & & 7.085 & & 7.383 & & 7.036 \\
\hline
\end{tabular}

Berdasarkan hasil analisis QSPM menunjukkan bahwa prioritas I implementasi strategi dari keempat alternatif strategi tersebut adalah strategi ke-3 yaitu perusahaan bekerjasama dengan pemerintah untuk melakukan pembinaan rutin kepada petani dengan Total Attractiveness Score (TAS) tertinggi sebesar 7,383. Dengan demikian, nilai TAS dari alternatif strategi tertinggi dapat dijadikan sebagai strategi Corporate Social Responsibility (CSR) melalui program Desa Makmur Peduli Api (DMPA) di bidang pertanian pangan khususnya usahatani jagung oleh PT Finnantara Intiga Di Kabupaten Sanggau. Berdasarkan faktor internal kelemahan, produksi jagung yang rendah dikarenakan petani cenderung lemah di kemampuan memanajerial usahatani jagung. Sedangkan dalam faktor ekternal peluang, permintaan jagung di Kabupaten Sanggau tinggi. Maka dari itu strategi ini dapat dilakukan dengan cara perusahaan menyediakan fasilitator untuk membina petani dan bekerjasama dengan pihak PPL untuk membina kelompok tani, dengan menggunakan lahan dan sarana produksi yang telah diberikan perusahaan untuk berusahatani jagung, sehingga petani dapat memenuhi permintaan pasar dan meningkatkan kualitas sumberdaya manusia dengan menjalankan program 
Sekolah Lapang Pengelolaan Tanaman Terpadu (SL-PTT), serta mengadakan magang atau studi banding ke daerah sentra pengembangan tanaman jagung. Sejalan dengan penelitian Nainggolan et al. (2014) mengatakan bahwa perbaikan kualitas SDM diharapkan mampu memberikan pengaruh positif terhadap kinerja petani. Hal ini diperkuat Nainggolan (2015) yang mengatakan bahwa keterlibatan perusahaan didukung dengan sistem manajemen yang baik dan SDM yang memiliki komitmen tinggi serta skill yang sesuai didukung dengan sumber daya finance akan membuat program CSR terlaksana dengan baik.

\section{KESIMPULAN}

Berdasarkan hasil analisis matriks SWOT menunjukkan strategi yang diimplementasikan adalah strategi WO (Weaknesses dan Opportunities) dengan 4 alternatif strategi. Berdasarkan hasil analisis QSPM diantara empat alternatif strategi, maka prioritas utama strategi terpilih yang dijadikan sebagai strategi peningkatan kinerja Corporate Social Responsibility (CSR) melalui program Desa Makmur Peduli Api (DMPA) di bidang pertanian pangan khususnya usahatani jagung oleh PT Finnantara Intiga Di Kabupaten Sanggau, yaitu perusahaan bekerja sama dengan pemerintah untuk melakukan pembinaan rutin kepada petani.

Pemerintah (Dinas Pertanian kabupaten Sanggau) menyusun dan melaksanakan program penyuluhan usahatani jagung kepada petani Desa Mengkiang secara rutin. PT Finnantara Intiga juga melakukan kolaborasi dengan lembaga praktisi dibidang pertanian, akademisi seperti SMK pertanian, Universitas untuk membangun kapasitas dan transfer knowledge kepada petani. Selain itu, perlu juga membangun jaringan pasar guna memaksimalkan serapan jagung. Penting juga untuk melakukan studi banding ke daerah sentra pengembangan tanaman jagung yang telah berkembang sehingga program perberdayaan Desa Makmur Peduli Api (DMPA) dapat berjalan lebih maksimal dan kesejahteraan petani dapat terwujud.

\section{DAFTAR PUSTAKA}

Antriyandarti, E., \& Ani, S. W. (2017). Pengembangan Kawasan Agribisnis Jagung Dan Mangga Di Kabupaten Blora. JSEP (Journal of Social and Agricultural Economics), 10(2), 43-50. https://doi.org/10.19184/jsep.v10i2.5653

Anwar, \& Muhammad. (2019). Strategi Pengembangan Usahatani Jagung (Zea Mays L.) Di Kecamatan Aikmel Kabupaten Lombok Timur. Journal Ilmiah Rinjani, 7(2), 218-227.

David, F. R. (2016). Strategic Management Consepts and Cases. Prentice Hall.

Haryati, Y., \& Anna, S. (2016). Pengujian Adaptasi Beberapa Varietas Jagung Hibrida Spesifik Lokasi Di Kabupaten Majalengka. Jurnal Agrotek Lestari, 2(1), 51-58.

Musna, M., Alam, M. N., \& Rauf, R. A. (2016). Strategi Pengembangan Agribisnis Jagung di Kecamatan Ampana Tete Kabupaten Tojo Una-Una. Jurnal Agroland, 23(1), 40-49.

Nainggolan, A. F. (2015). Strategi Pelaksanaan Program Corporate Social Responsibility (CSR) Pada PT. Riau Andalan Pulp and Paper Di Kabupaten Pelalawan. Jurnal Online Mahasiswa FISIP, 2(1), 1-10.

Nainggolan, S. P., Sihombing, L., \& Salmiah. (2014). Strategi Pengembangan Usahatani 
Jagung Di Kabupaten Dairi Kecamatan Tigalingga Desa Lau Sireme. Journal On Social Economic Of Agriculture Ang Agribuisness, 2(6), 1-14.

Nikoyan, A., Alwi, L. O., \& Yasnoni. (2019). Analisis Kinerja Pemberdayaan Masyarakat Dalam Program Corporate Social Responsibility: Studi Kasus PT. Antam TBK di Desa Hakatutobu, Kecamatan Pomalaa, Kabupaten Kolaka, Provinsi Sulawesi Tenggara. JSEP (Journal of Social and Agricultural Economics), 15(2), 173-184.

Pusparini, P. G., Yunus, A., \& Harjoko, D. (2018). Dosis Pupuk NPK Terhadap Pertumbuhan dan Hasil Jagung Hibrida. Agrosains: Jurnal Penelitian Agronomi, 20(2), 28-33.

Rahayu, W., Barokah, U., \& Fajarningsih, R. U. (2020). Strategi Pengembangan Usahatani Jagung Pada Lahan Kering Di Kabupaten Wonosobo. Jurnal AGRISEP Kajian Masalah Sosial Ekonomi Pertanian Dan Agribisnis, 19(1), 207-218.

Rangkuti. (2018). Analisis SWOT: Teknik Membedah Kasus Bisnis Cara Perhitungan Bobot, Rating dan OCAI. Gramedia Pustaka Utama.

Saharjo, B. H., \& Waldi, R. D. (2019). Strategi Pengendalian Kebakaran Hutan Di IUPHHK-HT PT Finnantara Intiga Provinsi Kalimantan Barat. Jurnal Silvikultur Tropika, 10(01), 7-14.

Salatan, S., Manoppo, V. E. N., \& Darwisito, S. (2018). Strategi Pemberdayaan Masyarakat Nelayan Soma Pajeko Di Kecamatan Salibabu Kabupaten Kepulauan Talaud Sulawesi Utara. Jurnal Sosial Ekonomi Kelautan Dan Perikanan, 13(1), 8797.

Santoso, S. (2016). Konsep Corporate Social Responsibility Dalam Perspektif Konvensional Dan Fiqh Sosial. Ahkam: Jurnal Hukum Islam, 4(1), 81-104.

Sidabutar, P., Savira, F., \& Suharsono, Y. (2014). Analisis Usahatani Jagung (Zea Mays) di Desa Dosroha Kecamatan Simanindo Kabupaten Samosir Provinsi Sumatera Utara. Journal of Chemical Information and Modeling, 1(1), 1-14.

Sugiyono. (2017). Metode Penelitian Kuantitatif Kualitatif dan R\&D. Alfabeta.

Yusuf, H., Hasnudi, \& Lubis, Y. (2014). Analisis Faktor-Faktor Yang Mempengaruhi Produksi Jagung Di Kabupaten Aceh Tenggara. Jurnal Agrica, 7(2), 65-73. 